\title{
Ortaöğretim Öğrencilerinin Atom Kavramını Anlama Seviyelerinin Tespiti
}

\author{
Ali KAYA* \\ Gümüşhane Üniversitesi, Mühendislik ve Doğa Bilimleri Fakültesi \\ akaya290@gmail.com
}

DOI: $10.21666 /$ muefd.309222

\begin{abstract}
$\ddot{O}_{z e t}$
Bu çalışmanın amacı, ortaöğretimde öğrenim gören öğrencilerin atom kavramını anlama seviyelerini tespit edebilmektir. Bu araştırmada betimsel yöntem kullanılmıştır. Çalışma verileri, yedi devlet lisesinden toplam 271 son slnıf öğrencisine geliştirilen 12 maddelik bir testin uygulanması ve 10 ögrenci ile olaylarla ilgili yapılan mülakatlardan (interview-about-events) elde edilmiştir. Testtin güvenirlik katsayısı 0,72 dir. Veriler frekans ve yüzde olarak verilerek analiz edilmiştir. Elde edilen bulgularda ortaögretim öğrencilerinin dörtte üçüne yakınının atom kavramını anladıkları görülmüştür. Öğrencilerin yaklaşı \% 42 'nin atom kavramını anlamadıkları ve bu konuda yanlış anlamalarının olduğu görülmüşü̈r. Öğrencilerin atom kavramı ile ilgili yanlış anlaması "Atom, maddenin parçalara ayrılamayan en küçük yapı taşıdır” yargısıdır. Öğrencilerin çoğunluğunun atomun yapısını kısmen anladiğı ve yaklaşık \% 20 'sinin anlamadıkları ve bu konuda yanlış anlamalarının olduğu görülmüştür. Öğrencilerin atomun yapısı ile ilgili yanlış anlamalarl; "Atom, küre şeklindedir", "Atomun çekirdeği bir küre şeklindedir", "Elektronlar atomda belli yörüngelerde hareket ederler." ve "Atom, çekirdek, elektron ve yörüngelerden oluşur" şeklindeki ifadelerdir. Ortaögretim ögrencilerinin atom kavramını anlama seviyelerinin yüksek olmasına rağmen, çoğunun atomun yapısını kısmen anladıkları ve her iki alanda da bazı yanlış anlamalarının olduğu tespit edilmiştir. Öğrencilerin yarısından fazlasının atom altı kuark, lepton, gluon, müon ve benzeri gibi parçacıklardan haberdar olmadıkları belirlenmiştir. Çalışma sonunda, atom kavramı ve yapısı ile ilgili sorunların giderilmesine yönelik önerilere yer verilmiştir.
\end{abstract}

Anahtar Sözcükler: Anlama Seviyesi, Atom, Kavram, Ortaöğretim

\section{Assessing High School Students' Levels Of Understanding Of The Atom Concept}

\begin{abstract}
The aim of this study is assessing high school students' levels of understanding of the atom concept. The descriptive research method was used in this study. The data for the study has been obtained from a total of 271 senior class students from seven state high schools by applying a 12 item test and a further interview-about-events interview of 10 students. The reliability coefficient has been found as 0,72. The data has been analyzed as frequencies and percentages. The findings showed that nearly three quarters of secondary education students comprehended the atom concept. Nearly $42 \%$ of them did not understood the atom concept and related misconceptions have been determined. The first misconception was the statement that "The Atom is the smallest particle of matter that is indivisible into it's particles". It has been further found that most students partially understood the constitution of the atom and that $20 \%$ did not understand, and misconceptions in this issue have been noted. The misconceptions were that "the atom was in the shape of a sphere", "the nucleus of the atom was sphere shaped", "the electrons moved on particular trajectories" and "the atom consists of a nucleus, electrons and trajectories". Although the understanding levels of high school students of the atom concept was found as high, most of them understood the structure of the atom incomplete and some misconceptions on both issues existed. It has been found that half of the students were unaware of sub-atom particles as quarks, leptons, gluons, muons and similar particles. The conclusion of the study involved suggestions aimed at the resolution of the misconceptions and deficits.
\end{abstract}

Keywords: The Atom, Level of Apprehension, Concept, Secondary Education.

Kavramlar; olaylar, varlıklar, insanlar ve düşünceleri benzerliklerine göre gruplandırıldığında gruplara verilen adlardır. Kavramlar bilginin yapı taşları olup, insanların öğrendiklerini sınıflandırmalarını ve organize etmelerini sağlarlar. Kavram öğretiminde, kavramı pozitif ve negatif yönleriyle tanıma ve farklı kavramları birbirinden ayırma süreci işletilir. Eğitim öğretimde kavram öğretimi önemli bir yere

\footnotetext{
*Yrd. Doç. Dr. Ali KAYA, alikaya@gumushane.edu.tr
} 
sahiptir. Öğrencilerin gelecek eğitimleri için kavramların doğru öğretilmesi olumlu katkılar sağlayacaktır. Bu nedenle günümüzde kavram öğretimi ile ilgili bir çok araştırma yapılmaktadır. Bunlar çoğunlukla kavram öğretim yöntemlerinin başarı durumlarının karşılaştırılması, kavramların anlaşılma seviyeleri ve kavram yanılgıları üzerine yoğunlaşmaktadır.

Fizik ve Fen eğitiminde de kavramlarla ilgili araştırmalar yapılmaktadır (Anderson ve Karrquist 1983; Feher ve Meyer 1992; Harrison ve Treagust 1996; Büyükkasap ve Samanc1 1998; Yıldız 2000; Epik ve diğ. 2001; Ergun, 2002; Ayas ve Özmen 2002; Gülçiçek ve diğ., 2003; Çökelez ve Dumon 2005; Y1ldız 2006; Adbo ve Taber 2009; Kaya 2010; Ergin, 2011; Kaya ve Ergun 2012; Sarıkaya ve Ergün, 2015; Demirci ve diğ, 2016; Yaseen ve Akangül., 2016). Atom kavramı ile ilgili yapılan araştırmalara bakıldığında genelde atom kavramını anlama düzeyi, atom kavramının öğretiminde kullanılan yöntemlerin araştırıldığı görülmektedir (Yıldız 2006; Kaya 2010; Ergin, 2011; Sarıkaya ve Ergün, 2015; Demirci ve diğ, 2016; Yaseen ve Akangül., 2016). Yıldız (2006) yaptığı araştırmada "Öğrencilerin derslerde kullanılan benzeşimlerden etkilendiği ve atomun yapısı ile ilgili zihinsel modellerini bu yönde yapılandırdı̆̆g" sonucuna ulaşmıştır. Ayrıca bu çalışmada ilköğretim öğrencilerinin atomun yapısı ile ilgili zihinsel modellemelerinin ders ve kaynak kitapları, internet, televizyon gibi çeşitli görsel unsurlarda karşılaştıkları yanlış resimlerle de bağlantılı olduğu belirtilmiştir. Kaya (2010) yapmış olduğu araştırmada 62 Fen Bilgisi öğretmen adayının atom kavramını anlama seviyelerinin \% 84 civarında olduğu ve $\% 6$ düzeyinde de yanlış anlamalarının olduğunu belirlemiştir. Yyine bu araştırmada öğretmen adaylarının "Atom, maddenin bölünemeyen en küçük yapı taşıdır" şeklinde yanlış anlamalarının olduğu tespit edilmiştir. Ergin (2011) Fizik Öğretmen adaylarının atomu oluşturan temel ve birleşik parçacıklarla ilgili görüşlerini belirlemeye yönelik bir araştırma yürütmüştür. Bu araştırmada fizik öğretmen adaylarının atom altı temel ve bileşik parçacıklar konusunda yeterli bilgiye sahip olmadıklarını belirlemiştir.

Atom, yapı olarak mikroskobik boyuttan da çok küçük olduğu için atomun yapısı konusunda ki çalışmaların çoğu son yüz elli yıl içerisinde gerçekleşmiş ve bir kısım çalışmalarda hala devam etmektedir. 1872 y1lında elektronun, 1914 yılında protonun ve 1932 y1lında da nötronun keşfinden sonra atomun bu parçacıklardan oluştuğu Rutherford atom modeli ile kabul edilmiştir. Daha sonra yapılan araştırmalarla 1960'lı yıllara gelindiğinde atomda bu parçacıklardan daha küçük parçacıkların da olduğu belirlendi (Ergin, 2011). Günümüzde maddenin yapısı konusunda ortaya konan Standart Modele göre, evrende temel parçacıklar olarak sadece altı çeşit kuark, altı çeşit lepton ve bunların karşıt parçacıkları ile foton, sekiz çeşit gluon ve üç çeşit vektör bozonundan oluşan kuvvet taşıyıcı parçacıklar ve bu parçacıklarla etkileşime girerek onlara kütle kazandıran Higgs bozonunun olduğu belirtilmektedir (Karaman, 2010). Atomun yapısını inceleyen Parçacık Fiziği'ne dair kavram ve konular eğitim sistemimiz içinde ikibinli yıllardan sonra yer almaya başlamıştır. Eğitim öğretim sistemimizde öğrenci merkezli eğitime dayalı yapılandırmacı öğrenme kuramına göre oluşturulan ve 2010-2011 EğitimÖğretim yılında kullanılmaya başlanan 11. sınıf Kimya ders kitabında 5. ünite de yer verilen "Çekirdek Kimyası" ünitesinde “Kuark, Gluon, Nötrino, Foton, Madde-Antimadde” kavramlarına ilişkin konuların ilk kez yer aldığı görülmektedir. Ortaöğretimde 2011-2012 Eğitim-Öğretim yılında kullanılmaya başlanan 12. sınıf Fizik Ders Kitabının 6. Ünitesi olan "Atomlardan Kuarklara” ünitesiyle "Parçacık ve Karşıt Parçacık, Hadronlar, Leptonlar, Baryonlar, Mezonlar, Kuarklar ve Karşıt Kuarklar" kavramları fizik müfredatında ilk defa yerini almıştır (Ergin, 2011). Eğitim kurumlarının bilimsel gelişmeleri takip etmede ve öğretim programlarına aktarmakta geç kaldıkları görülmektedir.

Atom kavramını öğrencilerin anlama seviyelerinin belirlenmesi konusunda ortaöğretimde araştırma yapılmadığı görülmektedir. Atom kavramı, öğrencilerin fizik ve kimya derslerinde maddenin yapısı ve ışığın oluşumu arasındaki ilişkiyi anlayabilmelerin açısından önemlidir. Fizik eğitiminde, öğrencilerin atomun yapısı ve özellikleri bilgisine sahip olmaları elektromanyetik 1şıma olayı ve magnetizmayı anlamalarında önemli bir yere sahiptir. Öğrencilerin elektrik akımı, elektrostatik, manyetizma, elektromanyetik indüksiyon, optik gibi konuların kavramalarında atom kavramı ve yapısının iyi bilinmesi gerekmektedir. Bu nedenlerden dolayı, ortaöğretimde öğrencilerin atom kavramları ile ilgili yanlış anlamaları ve eksik bilgileri onların Fizik ve Kimya alanları ile ilgili yukarıda belirtilen konuları anlamalarını zorlaştıracağı gibi, ileride ki eğitimlerini güçleştirecek, yanlış anlamalara neden olabilecek ve dolayısıyla öğrencilerin fen bilimleri derslerine ilgilerini azaltabilecektir. $\mathrm{Bu}$ tür sorunların yaşanmaması için bu temel kavramı ortaöğretim öğrencilerinin hangi düzeyde anladıklarının ve bu alanda ne tür yanlış anlamaların olduğu tespit edilerek çözüm yollarının belirlenmesi gereklidir. 
Araştırmanın amacı, ortaöğretimde eğitim gören öğrencilerin atom kavramını anlama seviyelerinin belirlenmesi amaçlanmıştır.

$\mathrm{Bu}$ araştırma ile ortaöğretim öğrencilerinin, Atom kavramını hangi düzeyde anlamışlar? Atomun yapısını bilyorlar mı? Bu iki konuda yanlış anlamaları var mı? Sorularına cevap aranacaktır.

\section{Yöntem}

$\mathrm{Bu}$ araştırmanın amacına uygun olarak örnek olay yöntemi kullanılmıştır. Örnek olay çalışmaları özellikle bireysel yürütülen çalışmalar için çok uygundur. Bunun nedeni, bu yöntemin araştırılan problemin bir yönünün derinlemesine ve kısa sürede çalışılması imkânı sağlamasıdır. Ayrıca bu yöntem ile tüm veri toplama araçlarının (anket, mülakat, vd.) kullanılması da mümkündür (Çepni, 2001). Böylece, kısa zamanda öğrencilerin atom kavramını ve yapısını anlama seviyelerinin derinlemesine yönelik birçok veri toplama aracı kullanılması imkânı bulunmuştur. Araştırma verileri geliştirilen bir test ve olaylarla ilgili mülakatlar (interview-about-events) yoluyla elde edilmiştir.

Araştırmada kullanılan test literatürden alınmıştır (Kaya, 2010). Hazırlanan test fizik eğitimi alanında uzman iki öğretim üyesine incelettirilmiştir. Ayrıca, testin pilot uygulaması Fen Bilgisi Öğretmenliği 1. sınıf öğrencilerinden random usulü ile seçilen 20'si ile yapılmıştır. Testin alfa güvenirlik katsayısı 0,72 olarak hesaplanmıştır. Test iki bölümden oluşmaktadır. Testin birinci bölümünde atom kavramı ve yapısının öğrenciler tarafından ne kadar anlaşıldığını belirlemeye yönelik 2 tane açık uçlu soru yer almaktatır. Testin ikinci bölümünde ise, atom kavramı ve yapısı ile ilgili 10 yargı verilerek öğrencilerden, verilen yargıların doğru, yanlış, fikrim yok şeklinde görüşlerini işaretlemeleri istenmiş ve her bir yargıya verdikleri cevapların nedenini açıklamaları için bir sütuna yer verilmiştir. Test Gümüşhane ve Ağrı il merkezlerinde yedi ortaöğretim kurumu son sınıfında öğretim gören 304 öğrenciye uygulanmıştır. Bunlardan 33 tanesi cevapların bir kısmının boş bırakılması ve cevap vermede özen gösterilmediği belirlenmesi üzerine değerlendirmeye katılmamıştır. Değerlendirmeye 95 Meslek Lisesi ve 176 Anadolu Lisesi öğrencilerinden oluşan toplam 271 öğrencinin cevapları alınmıştır.

$\mathrm{Bu}$ araştırma için kullanılan mülakat metodu daha önce Kaya (2010) tarafından yapılan benzer çalışma için yapılandan uyarlanmıştır. Mülakat sorularının hazırlanmasında fizik eğitimi alanında uzman iki öğretim üyesinin görüşleri alınarak son şekli verilmiştir. Bu tür mülakatlar, olaylarla ilgili yapılan mülakatlar (interview-about-events) olarak tanımlanmaktadır. Burada öğrencilere atomun yapısı ile ilgili resimler gösterilerek doğru olup olmadığı ve nedeni sorulmak suretiyle gerçekleştirilmiştir.

Ögrencilerin testin birinci bölümünde sorulara verdikleri yazılı cevaplar "anlama", "kısmen anlama", "yanlış anlama", "anlamama" ve "cevap vermeme" şeklinde sınıflandırılarak analiz edilmiştir. Elde edilen sonuçlar frekans ve yüzde değerlerihesaplanarak tablolar halinde verilerek yorumlanmıştır.

Öğrencilerin testin ikinci bölümünde "doğru", "yanlış" ve "fikrim yok" şeklinde verdikleri cevaplar frekans ve yüzdeleri hesaplanarak analiz edilmiştir. Öğrencilerin boş bıraktıkları yargılar da "fikrim yok" kategorisi içerisine dâhil edilmiştir. Ayrıca, öğrencilerin verdikleri cevaplarla ilgili açıklamaları da frekansları ile olduğu gibi verilmiştir.

\section{Bulgular}

Araştırmanın bulgu ve yorumları, testin birinci, ikinci bölümünden ve mülakatlardan elde edilen bulgular olmak üzere üç başlık altında verilmiştir.

\section{Testin Birinci Bölümünün Analizinden Elde Edilen Bulgular}

Öğrencilerin testin bu bölümünde sorulara verdikleri cevaplar, "anlama, kısmen anlama, yanlış anlama, anlamama ve cevapsız" kategorilerine ayrılarak frekans ve yüzdelikleri hesaplanmıştır. Bu şekilde analizlerden elde edilen bulgular toplu olarak aşağıda Tablo 1 ve Tablo 2'de verilmiştir. Bu araştırmanın amaçlarından biri de öğrencilerin bu kavramlarla ilgili yanılgılı olan düşüncelerini belirlemektir. Bundan dolayı, öğrenci cevaplarında "Kısmen Anlama" ve "Yanlış Anlama" kategorisinde yer alanlar ayrıntılı olarak incelenerek öğrencilerin yanılgılı olan düşünceleri tespit edilmeye çalışılmıştır.

Bu bölümde ilk olarak açık uçlu olarak "Atom nedir? Kısaca açıklayınız." Sorusu sorulmuştur. Öğrencilerin bu soruya, "Bir elementin tüm özelliklerini taşıyan en küçük birimine o elementin atomu denir." cevabını vermeleri beklenmiştir. Burada amacımız, öğrencilerin atom kavramını anlama seviyelerini kendi yazılı ifadeleri ile belirlemektir. 
Bu soruya verilen cevaplardan "kismen anlama" kategorisinde yer alanlar; "atom, maddenin en küçük yapı taşıdır","atom, maddenin en küçük yapısıdır" ve "atom, maddenin en küçük yapı birimidir", "atom, maddenin en temel parçasıdır": "yanlış anlama" kategorisinde yer alanlar; "atom, hücrenin en küçük yapı taşıdır", "atom, maddenin parçalara ayrılamayan en küçük yapı taşıdır" ve "atom, hücrenin en küçük yapı birimidir": "anlamama" kategorisinde alınan cevaplar ise; "atom, ateş parçasıdır", "atom, sönmüş bir ateş parçasıdır", "atom, kıvılcımdır", "atom, küçük çekirdekten oluşmuş görülmez maddedir", "atom, çekirdeğin en küçük yapı taşıdır", "atom, elektronların en küçük yapı taşlarıdır", "atom, maddeyi oluşturan var olmasını sağlayan etkendir" ve "atom, kütlesi ve hacmi olan her şeydir" şeklindedir.

Tablo 1. Öğrencilerin atom kavramını anlama seviyeleri

\begin{tabular}{|c|c|c|c|c|c|c|c|c|c|c|}
\hline & \multicolumn{2}{|c|}{ Anlama } & \multicolumn{2}{c|}{ Kismen Anlama } & \multicolumn{2}{c|}{ Yanlıs Anlama } & \multicolumn{2}{c|}{ Anlamama } & \multicolumn{2}{c|}{ Cevapsız } \\
\cline { 2 - 11 } & $f$ & $(\%)$ & $f$ & $(\%)$ & $f$ & $(\%)$ & $f$ & $(\%)$ & $f$ & $(\%)$ \\
\hline Sonuçlar & 16 & 6 & 200 & 74 & 31 & 11 & 16 & 6 & 8 & 3 \\
\hline
\end{tabular}

Tablodan, öğrencilerin atom kavramı ile ilgili kısmen anlamalarını da anlama seviyesi olarak alınırsa \% 80 oranında atom kavramının anlaşıldığı söylenebilir. Yine tablodan öğrencilerin \% 11yanlış anlamaya, $\% 9$ cevapsız ve anlamama seviyelerine sahip oldukları görülmektedir.

Testin birinci bölümünde sorulan ikinci açık uçlu soru "Atomun yapısı nasıldır? Şekli, içinde bulundurduğu parçacıklar ve bunların durumu vb.. kısaca açıklayınız." ş̧eklindedir. Öğrencilerin bu soruya, "Ortada proton ve nötronlardan oluşan çekirdek ve onun çevresinde belli enerji düzeylerinde hareket halinde bulunan elektronlar bulunmaktadır. Ancak son zamanlarda yapılan araştırmalarda atomda bu parçacıklardan daha küçük olan kuark, lepton, gluon, müon ve benzeri gibi parçacıklarında bulunduğu tespit edilmiştir." cevabını vermeleri beklenmiştir. Burada amacımız, öğrencilerin atomun yapısını anlama seviyelerini kendi yazılı ifadeleri ile belirlemektir.

Bu soruya verilen cevaplardan "kısmen anlama" kategorisinde yer alanlar; "Atom ortada proton ve nötronlardan oluşan çekirdek ve onun çevresinde belli enerji düzeylerinde hareket halinde bulunan elektronlardan oluşur", "atom, proton, nötron, elektron ve çekirdekten oluşur", "atom, proton, nötron ve elektrondan oluşur", "atom, proton, nötron ve çekirdekten oluşur", "atom, proton ve elektrondan oluşur", "atom çok küçüktür gözle görülmez proton, nötron ve elektrondan oluşur", "atomun belli şekli yoktur proton, nötron ve elektrondan oluşur" ve "atom, proton ve nötrondan oluşur" şeklindedir. "yanlış anlama" kategorisinde yer alanlar; "atom, küre şeklindedir", "atom, proton, elektron, nötron, yörünge ve çekirdekten oluşur" ve "atom, çekirdek, elektron ve yörüngelerden oluşur" şeklindedir. "anlamama" kategorisinde alınan cevaplar ise; "atom, gözle görülemeyen bir parçadır", "atom, dünyada bulunan kıvılcımlardır", "atom, küçük çekirdekler halindedir", "atom, moleküllerin en küçük yapısından oluşur", "atom, molekül şeklindedir, sayılamayacak kadar parçacık vardır" ve "atom, taneciklerden oluşmuştur" şeklindedir.

Tablo 2. Öğrencilerin atomun yapısını anlama seviyeleri

\begin{tabular}{|c|c|c|c|c|c|c|c|c|c|c|}
\hline & \multicolumn{2}{|c|}{ Anlama } & \multicolumn{2}{|c|}{ Kısmen Anlama } & \multicolumn{2}{c|}{ Yanlıs Anlama } & \multicolumn{2}{|c|}{ Anlamama } & \multicolumn{2}{c|}{ Cevapsız } \\
\cline { 2 - 11 } & $f$ & $(\%)$ & $f$ & $(\%)$ & $f$ & $(\%)$ & $f$ & $(\%)$ & $f$ & $(\%)$ \\
\hline Sonuçlar & 16 & $\mathbf{6}$ & 205 & $\mathbf{7 6}$ & 23 & $\mathbf{8}$ & 11 & $\mathbf{4}$ & 16 & $\mathbf{6}$ \\
\hline
\end{tabular}

Öğrencilerin \% 6'sı atomun yapısı tam olarak anladıkları, \% 70'in kısmen anladığı, \% 8 oranında da yanlış anlamalarının olduğu ve boş bırakılan cevapları da anlamama olarak alındığın da \% 10 oranında da atomun yapısını anlamadıkları görülmektedir.

Testin İkinci Bölümünün Analizinden Elde Edilen Bulgular

Testin ikinci bölümüne öğrencilerin verdikleri cevaplar aşağıda Tablo 3. de verilmiştir. 
Tablo 3. Öğrencilerinin atom ile ilgili yargılara verdikleri cevaplar

\begin{tabular}{|c|c|c|c|c|c|c|}
\hline \multirow{2}{*}{ Yargilar } & \multicolumn{2}{|c|}{$\mathrm{D}^{*}$} & \multicolumn{4}{|c|}{$\mathrm{Y}^{*} \quad$ F. $\mathrm{Y}^{*}$} \\
\hline & $\mathrm{f}$ & $\%$ & $\mathrm{f}$ & $\%$ & & $\%$ \\
\hline a. Atom bölünemeyen maddenin en küçük yapı tașıdır. & 90 & 33 & 168 & 62 & 13 & 5 \\
\hline b. Atom, hücrenin en temel ve basit yapısıdır. & 121 & 45 & 111 & 41 & 39 & 14 \\
\hline $\begin{array}{l}\text { c. Atom yapısında proton, elektron ve nötron bulunduran parçalara } \\
\text { ayrılamayan maddenin en küçük yapı taşıdır }\end{array}$ & 86 & 32 & 164 & 61 & 21 & 7 \\
\hline $\begin{array}{l}\text { d. Atom bir elementin kimyasal özelliklerini gösteren en küçük yap1 } \\
\text { taşıdır. }\end{array}$ & 210 & 77 & 24 & 9 & 37 & 14 \\
\hline $\begin{array}{l}\text { e. Atom ortasinda proton nötronlar bulunan çekirdek ve bu çekirdeğin } \\
\text { çevresinde hareket halinde elektronlardan oluşur. }\end{array}$ & 253 & 93 & 7 & 3 & 11 & 4 \\
\hline f. Elektronlar atomda belli yörüngelerde hareket ederler. & 202 & 74 & 51 & 19 & 18 & 7 \\
\hline g. Atomun çekirdeği bir küre şeklindedir. & 179 & 66 & 29 & 11 & 63 & 23 \\
\hline $\begin{array}{l}\text { h. Atomu oluşturduğu bilinen elektron, proton ve nötronlarda } \\
\text { kendilerinde daha küçük olan kuark, lepton, gluon, vb. parçacıklardan } \\
\text { oluşmuştur. }\end{array}$ & 156 & 58 & 43 & 16 & 72 & 27 \\
\hline $\begin{array}{l}\text { i. Atom bombası, kararsı atomların çekirdeğindeki zincirleme bölünme } \\
\text { reaksiyonunun bir anda ve patlama şeklinde olmasıyla ortaya çıkan } \\
\text { enerjidir. }\end{array}$ & 238 & 88 & 0 & $\mathbf{0}$ & 33 & 12 \\
\hline j. Nükleer enerji, atom çekirdeğinden elde edilen enerjidir. & 258 & 95 & 0 & $\mathbf{0}$ & 13 & 5 \\
\hline
\end{tabular}

Tabloda görüldüğü gibi öğrencilerin atomun yapısı ile ilgili "e" seçeneğin de yer alan kısmen doğru olan yargıy1 \% 93 oranında kabul ettikleri görülmektedir. Öğrencilerin \% 74'ü elektronların atom çevresinde belli yörüngelerde hareket ettikleri ile ilgili yanlış bilgi içeren "f" seçeneğine doğru demişlerdir. Yine öğrencilerin \% 33'ü "Atomu maddenin bölünemeyen en küçük parçasıdır" ve bu yargıyı farklı bir şekilde ifade eden "c" seçeneğine de \% 32'i oranında doğru demişlerdir. Öğrencilerin "d" seçeneğinde verilen atom kavramının bilimsel tanımına yüzde 77'ü doğru demiştir. Ayrıca, öğrencilerin yüzde 66's1 atomun çekirdeğinin yapısı ile ilgili "Atomun çekirdeği bir küre şeklindedir." seçeneğine doğru demişlerdir. Devam eden bilimsel araştırmalar sonucu atomun yapısı ile ilgili ulaşılan son bilgileri içeren "h" seçeneğindeki yargıdan öğrencilerin \% 58'i doğru demiştir. Öğrencilerin tamamına yakını atom bombası ve nükleer enerji kavramlarından haberdar oldukları görülmektedir. Ancak, öğrencilerin çoğunun atom altı kuark, lepton, gluon, müon ve benzeri gibi parçacıklardan haberdar olmadıkları görülmüştür.

Öğrencilerden verilen yargılara "Yanlış" cevabı verenlerin açıkladıkları gerekçelerden bazıları şöyledir; "a" seçeneği için 22 öğrenci atomun parçalanabileceğini belirterek olumlu açıklama yapmıștır, 2 öğrenci "Maddenin en küçük yapı taşıdır", 3 öğrenci ise "Atomdan daha küçük parçacıklar vardır" şeklinde ifadelerde bulunmuşlardır. "b" seçeneği için 13 öğrenci "Atom, hücrenin değil maddenin en temel ve basit yapısıdır" derken bir öğrenci de "Hücre ile atomun hiçbir ilgisi yoktur" demiştir. "c" seçeneği için 46 öğrenci "Atom parçalanabilir" diyerek anlamlı bir açıklama yapmıştır. "d" seçeneği için 2 öğrenci "Atom hücrenin en temel ve basit yapısıdır" şeklinde bir yanlış ifade ile açıklama yapmıştır. 5 öğrenci "d" seçeneği için "Elementlerin kimyasal yapısını göstermez" şeklinde bir yanlış ifade ile açıklama yapmıştır. Bir öğrenci "d" seçeneği için "Hem fiziksel hem de kimyasal özellik gösterir" şeklinde bir ifade ile açıklama yapmıştır. Bir öğrenci "g" seçeneği için "Nokta şeklindedir" derken diğer bir öğrencide "Herhangi bir şekilde olabilir", bir öğrenci de "Şekli belli değildir" şeklinde bir açıklamada bulunmuşlardır. "f" seçeneği için bir öğrenci "Elektronlar belli yörüngede dönmez" ve diğer biri de "Elektronların bu yörüngelerden geçtiği farz edilir" şeklinde olumlu bir açıklama yapmıştır. Öğrencilerden beş tanesi "h" seçeneğindeki yarg1 için "Böyle bir şeyler duydum fakat ayrıntılı bilmiyorum" ve on öğrencide "Bu konuda fikrim yok" ifadesini kullanmıştır. Öğrencilerin çoğunun atom kavramı ve atomun yapısı ile ilgili yargıların nedenlerini açıklamakta güçlük çektikleri görülmektedir. 


\section{Mülakattan Elde Edilen Bulgular}

Mülakatın birinci sorusunda, öğrencilere dört șekil gösterilerek atomun yapısının bu şekillerden hangilerinde doğru olarak gösterildiği sorulmuştur. Öğrencilerin tamamı birinci şekilde elektronlar için yörüngenin belirtilmemesini eksiklik olarak gördüklerini ifade etmişlerdir. Bundan dolayı da birinci şeklin atomun yapısını açılayamayacağını ifade etmişlerdir. Öğrenciler "Atomda elektronlar nasıl hareket ederler?" sorusu sorulmuştur. Öğrencilerden altısı "Elektronlar atomda belli yörüngelerde hareket ederler" şeklinde cevap vermiş̧tir. Dört öğrencide birinci şekilde elektronların yörüngelerinin belirtilmemesi yanında atomun çekirdeğinin küre şeklinde gösterilmemesini de diğer bir eksiklik olarak gördüklerini ifade ettiler.

Ögrencilerin tamamı ikinci şekil ile ilgili olarak, “Atomun yapısını izah etmede kullanılabilir” demiştir. Bunun nedenini sorduğumuzda öğrencilerin çoğu ders kitaplarının ve öğretmenlerinin atomu izah etmekte benzer şekli kullandıklarını ifade ettiler.

Öğrencilerin üçüncü şekille ilgili olarak dördü atomun yapısını açılayabilir, diğer dördü açıklayamaz ve geri kalanları da kısmen açıklayabilir şeklinde cevap vermişlerdir. Öğrencilerden bu şekil atomun yapısını açıklayabilir diyenler; şeklin üç boyutlu çizildiğini, elektronların yörüngelerinin belirtildiğini ve proton ve nötronların çekirdekte bir arada olduğundan dolayı üçüncü şeklin atomun yapısını açıklamak için yeterli olacağını belirttiler. Öğrencilerden bu resmin atomun yapısını kısmen açıklar diyenler ise, şekildeki eksikliğin çekirdeğin küre şeklinde olmaması olduğunu ifade etmişlerdir. $\mathrm{Bu}$ şeklin atomun yapısını açıklamada kullanılamaz diyenler ise, elektronların yörüngelerinin birbiriyle çakıştı̆̆ını ifade etmişlerdir. Öğrencilerden üçü bu şekli bilimsel dergi ve bazı kitaplarda gördüklerini ifade etmişlerdir.

Öğrencilerin tamamı dördüncü şekille ilgili olarak "Bu şekil atomun yapısını izah edemez" demişlerdir. Öğrencilerin tamamı bunun nedenini "Protonun çekirdekte yer alması gerekir" şeklinde ifade etmişlerdir.

\section{Tartışma}

Araştırmanın bulgularından aşağıdaki sonuçlar çıkarılmıştır. Elde edilen bulgulara göre, ortaöğretim ögrencilerinin atom kavramını anlama seviyeleri testin birinci bölümü (Tablo 1) anlama \%16 kısmen anlama \%74 ve ikinci bölümünde yer alan yargılarda (Tablo 3. d, h) \%77 ve \%58 dikkate alındığında öğrencilerin \% 56'sının atom kavramını anladıkları söylenebilir. Birinci bölümde kısmen anlama seviyelerinin yüksek olması öğrencilerin mevcut bilgilerini açıklamakta güçlük çektiklerini göstermesi bakımından önemlidir. Öğrencilerin açık uçlu sorularda atomun yapısını doğru olarak açıkladıkları cevapların testin ikinci bölümünde atomun yapısını doğru olarak açıklayan mevcut yargılara verdikleri cevaplardan düşük oranda olması bunu desteklemektedir. Buradan öğrencilerin var olan bilgilerinden tam emin olmadıkları duygusu öne çıkmaktadır.

Atom kavramı ile ilgili testin birinci bölümünde yanlış anlama olarak öne çıkan "Atomun maddenin bölünemeyen en küçük yapı taşıdır" ifadesi (Tablo 1) \% 11 oranında iken, testin ikinci bölümünde (Tablo 3. a, c) yaklaşık olarak öğrencilerin üçte biri tarafından doğru olarak kabul edilmiştir. Ortaöğretim öğrencilerinin yaklaşık beşte birinde (\%20) "Atomun maddenin bölünemeyen en küçük yapı taşıdır" yanılgısının mevcut olduğu tespit edilmiştir. Ortaöğretimde bu yanlış anlamanın yüksek olmasının nedenleri şunlar olabilir. Birincisi, atom kavramı miroskopik boyutta ve soyut olduğundan bilimsel olarak tanımlanması ve öğrenilmesinide ki zorluklar olabilir. İkincisi, atom kavramı konusundaki çalışmaların uzun zaman alması ve bu süreç içerisinde atom kavramı ile ilgili birçok teorilerin ortaya atılmış olması ve atom kavramının öğretiminde bu teorilerin tarihi sıralamasına göre yapılıyor olması olabilir. Öğrencilere atom kavramı konusunda ilk olarak Dalton'nun atom modeli verilmektedir. Bu model yukarıdaki yanlış anlamayı içermektedir. Öğrencilerin çoğunluğunun bu yanlış anlamaya bu modelin kendilerine sunumunda öğretmenler tarafından gerekli vurguların zamanında ve etkili yapılamamasının neden olduğu düşünülmektedir. Kaya'nın (2010) Fen Bilgisi öğretmen adayları ile yaptığı çalışmada da bu yanılgı $\% 6$ oranında gözlenmiştir. Burada oranın düşük olmasını, öğrencilerin fen alanında yükseköğrenim görmelerinin etkili olduğunu söyleyebiliriz. Ergun (2002) yaptığ araştırmada benzer bir sonuca ulaşmıştır. Bu araştırmada öğrencilerin toplu iğne ve su damlasının atomlarını cisimlerin minyatür hali olarak gösterdiklerini gözlemlemiştir. Ayrıca, öğrencilerin atomun şeklini top modeli ve tanecik modeli şeklinde çizdikleri gözlenmiştir. Öğretim programında atom modelinin bugünkü kabul edilen şekliyle değil de ilk model olan Dalton'un modeliyle başlayarak 
verilmesi öğrencileri bu yanılgıya yönlendirdiği belirtilmektedir (Kaya ve Ergun, 2012). Öğrencilerin atom kavramını anlamama seviyeleri testin birinci bölümünde birinci soruya cevap vermeyenler ve ikinci bölümündeki bu konu ile ilgili yargılara verdikleri "fikrim yok" cevaplarına bakıldığında yaklaşık olarak \% 10 civarında olduğu belirlenmiștir.

Öğrencilerin testin birinci bölümünde atomon yapısını anlama \%6 ve kısmen anlamaları \%76 birlikte değerlendirip (Tablo 2) ve testin ikinci bölümünde (Tablo 3. e, h) \% 93 ve \% 58 bu konuda ki yargılara verdikleri cevaplara bakıldığında \%58 düzeyinde olduğu görülmektedir. Bu değerin atom kavramını anlama seviyesine çok yakın çıkması manidardır. Öğrencilerin yarıdan fazlasının atom altı kuark, lepton, gluon, müon ve benzeri gibi parçacıklardan haberdar olmadıkları belirlenmiştir (Tablo 3. h). Burada atomun yapısı ile ilgili bilimsel çalışmaların hala devam etmesi ve bu konudaki gelişmelerin son yıllarda ortaya çıkmasının ve bu bilgilerin eğitim sistemine girmesinde ki gecikmelerin rolünün büyük olduğu söylenebilir. Günümüzde maddenin yapısı konusunda ortaya konan Standart Modele göre evrende temel parçacıklar olarak sadece altı çeşit kuark, altı çeşit lepton ve bunların karşıt parçacıkları ile foton, sekiz çeşit gluon ve üç çeşit vektör bozonundan oluşan kuvvet taşıyıcı parçacıklar ve bu parçacıklarla etkileşime girerek onlara kütle kazandıran Higgs bozonu vardır (Karaman, 2010). CERN (Avrupa Nükleer Araştırma Merkezi) İsviçre ve Fransa sınırında yer alan dünyanın en büyük parçacık fiziği laboratuvarında yapılan deneylerde 14 Mart 2013 tarihinde bilim adamları tanrı parçacığını yani Higgs bozonunu bulduklarını açıkladılar (URL 1). Ergin (2011) de yaptı̆̆ı araştırmada Fizik öğretmen adaylarının atom altı temel ve bileşik parçacıklar konusunda yeterli bilgiye sahip olmadıklarını belirlemiştir. Kaya'da (2010) Fen Bilgisi öğretmen adayları ile ilgili yaptığı benzer çalışmada öğrencilerin atom kavramının yapısını \% 37 tam \% 60'ıda kısmen anladıkları belirlemiştir. Bunda mevcut ders kitaplarının bilimsel gelişmeler doğrultusunda güncellemelerin zamanında yapılamaması, öğretmenlerin güncel bilimsel gelişmeleri takip edememeleri ve bu konuda yeterli hizmetiçi eğitim alamamalarının etkili olduğu düşünülmektedir. Öğrencilerin çoğunluğu atomun yapısı konusunda atom altı parçacıklardan (elektron, proton, nötron, vb.) bahsetmelerine rağmen, atomu maddenin en küçük yapı taşı demeleri, tamamına yakınının atom bombası ve nükleer enerjiden haberdar olmalarına rağmen atomun parçalanamayacağını söylemeleri sorulara verdikleri cevaplarda sahip oldukları bilgilerle ilgili yorum yapamadıklarını göstermektedir. Öğrenciler öğrenmeyi bazı temel kuralları ezberlemek olarak algıladıkları düşünülmektedir. Hâlbuki çağdaş eğitim yaklaşımında öğrencilerin bilgiyi sorgulayan, yorumlayan ve ondan sonuçlar çıkarabilen bireyler olmaları temel alınmaktadır. Bu yaklaşımın öğrencilerde tam olarak yerleşmediği görülmektedir.

Ortaöğretim öğrencilerinin atomun yapısı konusunda ki yanlış anlamaları testin birinci bölümü ikinci sorusuna verilen cevaplarda \% 8 iken testin ikinci bölümünde yer alan bu ifadelere (Tablo $3 . \mathrm{f}, \mathrm{g}$ ) sırasıyla $\% 74$ ve $\% 66$ oranlarında doğru demeleri bu yanılgıların onlarda olduğunu göstermektedir. Mülakatlardan elde edilen verilerinde öğrencilerin çoğunda benzer yanlış anlamaların var olduğunu göstermektedir. Öğrencilerin yarıdan çoğunda atomun yapısı ile ilgili farklı yanlış anlamalar olduğu tespit edilmiştir. Bu yanlış anlamalar; "Atom, küre şeklindedir", "Atomun çekirdeği bir küre şeklindedir.", "Elektronlar belli yörüngelerde hareket eder", "Atom, proton, elektron, nötron, yörünge ve çekirdekten oluşur" ve "Atom, çekirdek, elektron ve yörüngelerden oluşur" şeklindedir. Öğrenciler de bu yanılgıların oluşma nedeni konuyu sunan öğretmenlerin dersi sunum esnasında kullandıkları çizim, şekiller ve yaptıkları benzetmeler, ders kitapları ve diğer ansiklopedi ve internet gibi kaynaklarda atomun şekli küre ve elektronların yörüngeleri dairesel olarak gösteriliyor olması etkili olabilir. Ayrıca, Bohr atom modelinde de elektronların belli yörüngelerde dolandığı ifadesinin geçmesi de bunda etkili olabilir. Ergin (2011) yaptığı çalışmada Fizik öğretmeni adaylarında benzer yanılgıları belirlemiştir. Kaya da (2010) Fen Bilgisi öğretmen adayları ile yaptığı araştırmada benzer yanılgıların \% 58 "Elektronlar belli yörüngelerde hareket eder" ve \% 42 "Atomun çekirdeği bir küre şeklindedir" oranlarında olduğunu tespit etmiştir. Öğrencilerin sahip oldukları bu yanlış anlamaların nedeni konusunda derslerde kullanılan benzeştirmelerden etkilenmeleri ve atom kavramı ile ilgili zihinsel modellerini bu yönde yapılandırdıkları Yıldız (2006) tarafından ifade edilmektedir. Ayrıca bununla ilgili internet, televizyon gibi çeşitli görsel unsurlarda yapılan yayın ve anlatımlarda kullanılan olayı iyi örnekleyemeyen şekiller ve çizimlerin etkili olduğu belirtilmektedir (Novick ve Nussbaum 1981; Y1ldız, 2006). Mouly ve arkadaşları (1995) yaptkları araştırmada öğrenilecek ve öğrenilmiş bilgi arasında her öğretmenin ders kitaplarından, mesleksel deneyimlerinden, müfettişlerin yönlendirmelerinden ve öğrencilerin yeteneklerinden esinlenerek oluşturduğu didaktik çalışmaların etkilediği bir ayırımın 
olduğunu belirtmişlerdir. Yıldırım'da (2008) yaptığı çalışmada benzer sonuçlara ulaşmıştır. Novick ve Nussbaum (1981) da yaptıkları araştırmada kavram yanılgıların bir kısmının öğretmen ve öğretim materyallerden kaynaklandığı sonucuna varmışlardır.

Ortaöğretim öğrencilerinin atomun yapısını anlamama seviyelerini testin birinci bölümü ikinci soruya verdikleri cevaplar ve cevapsız bırakılanlarla \% 10 (Tablo 2) ve testin ikinci bölümünde bu konudaki yargılara (Tablo 3. e, f, g, h) \% 20 fikrim yok diyenlerin oranlarına bakılarak \% 15 civarında olduğu belirlenmiştir.

Öğrencilerin çoğunluğunun atom kavramını kısmen anladıkları ve atomun yapısı konusunda da yeterli bilgiye sahip olmadıkları görülmektedir. Bu durumun nedenlerinin araştırılarak ortadan kaldırılmasına yönelik tedbirlerin alınması onların bundan sonraki eğitimleri için yararlı olacaktır.

Öğretmenler tarafindan atom kavramının öğretimi sırasında kitaplarda yer alan tarihi sıralama takip edilirken yanlış olan ilk modeller ile günümüzde gelinen son noktanın öğrencilere iyi öğretilmesi ve gereken vurguların yerinde ve zamanında etkili yapılması gerekir.

Öğrencilerin atom kavramı ve atomun yapısı konusunda bir takım yanlış anlamalarının olduğu görülmektedir. Bu yanlış anlamaları ilk ve ortaöğretimde görev başında olan öğretmenlerden ve ders kitapları ile diğer yazılı öğretim materyallerinden kaynaklanıyor olabileceği düşünülmektedir. $\mathrm{Bu}$ konunun araştırılarak gerekli tedbirler alınmalıdır.

\section{Kaynakça}

Adbo, K., ve Taber, K. S. (2009). Learners' mental models of the particulate nature of matter: A study of 16-year-old Swedish science students. International Journal of Science Education, 31(6), 757786.

Anderson, B., ve Karrquist, C., (1983). How swedish pupils, aged 12-15 years, understand ligh and its properties. Journal of Science Education, 5(4), 316-322.

Ayas, A., \& Özmen, H. (2002). Lise kimya öğrencilerinin maddenin tanecikli yapısı kavramını anlama seviyelerine ilişkin bir çalışma, Boğaziçi University Journal of Education, 19(2), 45-60.

Büyükkasap, E., ve Samancı, O., (1998). İlköğretim Öğrencilerinin Işık Hakkındaki Yanlış Kavramaları, Kastamonu Ĕ̈itim Dergisi, 4, 109-120.

Çepni, S., Araştırma ve Proje Çalışmalarına Giriş, Erol Ofset, Trabzon, 2001.

Çökelez, A., ve Dumon, A. (2005). Atom and molecule: upper secondary school French students' representations in long-term memory. Cemistry Educaiton: Research and Practice in Europe, 6(3), 119-135.

Epik, Ö., Kalem, R., Kavcar, N., ve Çallıca, H., (Eylül 2001). "Işılk ve görüntü oluşumu" ile ilgili kavram yanılgılarının ve bilgi eksikliklerinin belirlenmesi üzerine bir çalışma, Yeni Binyılın Başında Türkiye'de Fen Bilimleri Eğitimi Sempozyumu Bildiri Kitab1, s.351-355, Maltepe Üniversitesi, İstanbul.

Ergin, A., (2011). Fizik öğretmen adaylarının temel ve birleşik parçacıklar ile parçacık hızlandırıcılarına dair görüşlerinin belirlenmesi. (Yayınlanmamış yüksek lisans tezi)

Balıkesir Üniversitesi, Fen Bilimleri Enstitüsü, Balıkesir.

Ergun, M. (2002). Etude des conceptions d'élèves de collège et de lycée sur l'atome et la structure de la matière, mémoire de DEA, Université Joseph Fourier (Grenoble 1).

Demirci, S., Yılmaz, A., ve Şahin, E., (2016) Lise ve üniversite öğrencilerinin atomun yapısı ile ilgili zihinsel modellerine genel bir bakış, Türkiye Kimya Derneği Dergisi, 1(1), 87-106.

Feher, E., \& Meyer, K. R., (1992). Children's conceptions of color. Journal of Research in Science Teaching, 29(5), 505-520.

Gülçiçek Ç., Bağı, N., ve Moğol, S., (Yaz 2003). Öğrencilerin atom yapısı-güneş sistemi pedagojik benzeştirme (anoloji) modelini analiz yeterlilikleri. Milli Ĕgitim Dergisi, 159.

Harrison A.G., ve Treagust, D.F. (1996). Secondary students' mental models of atoms and molecules: implications for teaching chemistry. Science Education, 80(5), 509-534.

Karaman T., (2010). CMS HCAL Detektöründe kullanılan hpd'lerin kalibrasyon çalışması. (Yayınlanmamış yüksek lisans tezi) Çukurova Üniversitesi, Fen Bilimleri Enstitüsü, Adana.

Kaya A., (2010). Fen bilgisi öğretmen adaylarının 1şık ve atom kavramlarını anlama seviyelerinintespiti, Erzincan Eğitim Fakültesi Dergisi, 10(1), 15-37. 
Kaya G., ve Ergun M., (2012). Didaktiksel dönüşüm teorisine göre maddenin tanecikli yapısı ünitesinin incelenmesi, Illköğretim Online, 11(4), 1101-1120. [Online]: http://ilkogretim-online.org.tr.

Mouly B., Genet-Volet, Y., ve Amade-Escot, C. (1995). Concevoir l'enseignement de la danse au Quebec: une dynamique complexe de mise en oeuvre des contenus enseignementetd' apprentissage.

Novick, S., ve Nussbaum, J. (1981). Pupils' understanding of the particulate nature of matter: a cross age study, Science Education, 65(2), 187-196.

Sarıkaya M., ve Ergün, A. (2015). İlköğretim ve ortaöğretim öğrencilerinin atom ve moleküllerin şekli üzerine bazı fiziksel etkenlerin etkisini anlamalarının araştırılması. Turkish Journal of Education, 3(3), 56-73.

URL 1. http://cerndeneyi.nedir.com/\#ixzz3J2toAYzU. (15.04.2014)

Yaseen Z., ve Akangül S., (2016). Lise öğrencilerinin atom ile ilgili zihinsel modellerinin ders kitaplarındaki görseller ile karşılaştııılması. Mehmet Akif Ersoy Üniversitesi Eğitim Fakültesi Dergisi, 40, 469-490.

Yıldız, T. H. (2006). Illköğretim ve ortaöğretim ögrencilerinin atomun yapıst ile ilgili zihinsel modelleri. (Yayınlanmamış yüksek lisans tezi) Balıkesir Üniversitesi, Fen Bilimleri Enstitüsü, Balıkesir.

Yıldırım, M. (2008). İlkögrretim fen ve teknoloji dersinde genetik ünitesinin bilimsel bilgilerden ögretmen bilgilerine geçişinin "didaktiksel dönüşüm teorisi” yaklaşımıyla değerlendirilmesi. (Yayınlanmamış doktora tezi) Marmara Üniversitesi, Eğitim Bilimleri Enstitüsü, İstanbul.

Yıldız, İ. (2000). İlköğretim 6. Sinıf ögrrencilerinin ışılk ünitesindeki kavram yanılgıları. Yayınlanmamış yüksek lisans tezi) KTÜ Fen Bilimleri Enstitüsü, Trabzon. 